UDC 669.017

D. Hlushkova, DSc, Prof.,

O. Voronkov, DSc, Prof.,

I. Kirichenko, DSc, Prof.,

O. Nikonov, DSc, Prof.

Kharkiv National Automobile and Highway University, 25 Yaroslava Mudrogo Str., Kharkiv, Ukraine, 61000; e-mail: diana@khadi.kharkov.ua

\title{
INCREASING OF WEAR RESISTANCE OF RESPONSIBLE PARTS OF THE HYDRAULIC BREAKER BY ION-PLASMA TREATMENT
}

\begin{abstract}
Д.Б. Глушкова, О.І. Воронков, І.Г. Кириченко, О.Я. Ніконов. Метод підвищення зносостійкості відповідальних деталей гідромолота іонно-плазмової обробки. Деталі гідромолота піддаються в процесі експлуатації інтенсивному абразивному зносу, що призводить до зменшення тривалості їх роботи. Питання підвищення зносостійкості займає особливе місце при вирішенні проблеми забезпечення необхідного ресурсу цих деталей. Відповідно до літературних даних, а також на підставі аналізу багаторічної практики експлуатації гідромолотів, використовується багато методів об'ємного і поверхневого зміцнення деталей, які не дають істотного ефекту. Тому актуальним стало залучення нових методів поверхневого зміцнення. До таких методів відноситься іонно-плазмове хромування. В якості задач роботи передбачалося проведення докладного аналізу пошкоджених робочих поверхонь деталей гідромолоту; дослідження змін структури та властивостей зміцнених поверхневих ділянок при експлуатації; розробка технологічного процесу зміцнення, який забезпечує підвищення зносостійкості деталей в результаті іонно-плазмового хромування. Досліджували поверхні деталей бойок і піку після поверхневого зміцнення і експлуатації. Отримані дані про характер i інтенсивності зносу по зонам і ділянкам кожної деталі. Високоякісні покриття хрому отримані при температурах підкладки не нижче $80-100^{\circ} \mathrm{C}$. На підставі експериментальних досліджень встановлено вплив іонно-плазмового хромування на зносостійкість $\mathrm{i}$ механічні властивості деталей гидромолота, а також проаналізовані структурні зміни в матеріалі. Після експлуатації поверхня деталі може мати такі дефекти, як задири, тріщини вздовж вісі деталей, втрата маси металу (зменшення товщини покриття), а також місцевий наклеп i деформація металу. Іонно-плазмове хромування деталей за запропонованою технологією підвищило їх зносостійкість в 1,75 рази в порівнянні з тими, що не зміцнювали. Технологія іонно-плазмового хромування забезпечує роботу зміцнених деталей без сколів і без викрашування. На ділянках пошкодження деталей відзначаються зони структурних перетворень, характерні для явищ вторинного гартування.
\end{abstract}

Ключові слова: іонно-плазмове хромування, гідромолот, опір зносу, покриття

D. Hlushkova, O. Voronkov, I. Kirichenko, $O$. Nikonov. Increasing of wear resistance of responsible parts of the hydraulic breaker by ion-plasma treatment. During operation, parts of the hydraulic hammer are subjected to intense abrasive wear, which leads to a decrease in the duration of their work. The issue of increasing wear resistance occupies a special place in solving the problem of ensuring the necessary resource of these parts. In accordance with the literature data, as well as on the basis of analysis of many years of experience in operating hydraulic hammers, many methods of volumetric and surface hardening of parts are used that do not give a significant effect. Therefore, it became relevant to attract new methods of surface hardening. These methods include ion-plasma chromium plating. As the tasks of the work, a detailed analysis of the damaged working surfaces of the hydraulic hammer parts was provided; the study of changes in the structure and properties of hardened surface areas during operation; development of the hardening process, providing increased wear resistance of parts as a result of ion-plasma chromium plating. We investigated the condition of the working surface of the critical parts of the hydraulic hammer - the hammer and peaks - after hardening and operation. Data were obtained on the nature and intensity of wear in the zones and sections of each part. High-quality chromium coatings were obtained at substrate temperatures not lower than $80-100^{\circ} \mathrm{C}$. Based on experimental studies, the effect of ion-plasma chromium plating on the wear resistance and mechanical properties of hydraulic hammer parts is proved, and structural changes in the material are analyzed. After operation, the surface of the part may have defects such as scuffing, cracks along the axis of the part, loss of metal mass (decrease in coating thickness), as well as local hardening and deformation of the metal. Ion-plasma chrome plating of parts according to the proposed technology increased their wear resistance by 1.75 times compared with unstressed. The technology of ion-plasma chromium plating ensures the operation of hardened parts without chips and without chipping. In areas of damage to parts, zones of structural transformations characteristic of secondary hardening phenomena are noted.

Keywords: ion-plasma chromium plating, hydraulic hammer, wear resistance, coating

\section{Introduction}

The development of modern technology imposes ever-increasing demands on the performance of critical parts of a hydraulic hammer. In the complex of problems of increasing their reliability and durability, the issue of wear resistance occupies a special place. Insufficient wear resistance limits the

\section{DOI: 10.15276/opu.2.61.2020.02}

(c) 2020 The Authors. This is an open access article under the CC BY license (http://creativecommons.org/licenses/by/4.0/). 
growth of the performance of hydraulic hammers and the terms of their operation, increases the cost of repairs and spare parts.

Increasingly, to solve the problem of improving the operational characteristics of materials, new methods of surface hardening are used, in particular, ion-plasma coating methods.

\section{Analysis of literary data and problem statement}

From the publications it follows that many hardening methods are used to increase the wear resistance of the working surfaces of machines, but all of them do not provide a significant increase in their durability $[1,2,3]$. Therefore, it was advisable to use ion-plasma technologies aimed at increasing the wear resistance of the working surfaces of parts operating under abrasive wear [4-7]. Over the past decade, interest in environmentally friendly vacuum coatings, in particular in PVD coating technologies (Physical Vapor Deposition), has grown in many industries [8]. One of the most advanced PVD technologies is coating deposition using an electric arc discharge in a vacuum. Vacuum arc coatings are characterized by high strength compounds with the base metal, have high resistance to frictional wear, erosion under the influence of cavitation, gas and dust flows, as well as good corrosion resistance under the influence of air atmosphere and corrosive environments [3]. Coatings are characterized by high density, the absence of cracks, good adhesion to the material of the workpiece, and can be obtained at relatively low heating temperatures $\left(\sim 350 \ldots 400^{\circ} \mathrm{C}\right)$ of the coated products [8].

The application of high voltage to the condensation surface for some time in the middle of the process leads to a suspension of grain growth and the formation of a fine-grained structure. The reason for its formation is considered to be the beginning of the process of coating spraying [9, 10], when there are many local defects that act as crystallization centers during further coating. Such a coating structure has higher protective properties against wear.

\section{Purpose}

Improving the wear resistance of critical parts of a hydraulic hammer by ion-plasma treatment.

\section{The objectives of the study}

Based on experimental studies, it is necessary to solve the following problems:

1. To analyze the damaged working surfaces of the tested parts of the hydraulic hammer according to the nature and location of the zones.

2. Develop a process for hardening. To provide increased wear resistance of parts hardened by ion-plasma chromium plating using advanced technology.

3. To study changes in the structure and properties of hardened surface areas of the investigated parts during operation.

\section{Research method}

The test results of parts hardened by ion-plasma chromium plating showed that before the coating breaks, good wear resistance of the hardened parts takes place $[8,9]$. Therefore, the right choice of ion-plasma chromium plating modes, which allows increasing the wear resistance of critical parts of a hydraulic hammer, is relevant $[10,11,12]$. Hardening treatment (ion-plasma chromium plating) was performed using an advanced technology that excludes overheating of parts during coating and its chipping during testing [13].

High-quality coatings of pure metals were obtained at substrate temperatures of at least $80 \ldots 100^{\circ} \mathrm{C}$. The initial technological materials for vacuum ion-plasma deposition are the cathodes of the sprayed metals, in this case chromium (BX-1). We used the Bulat-3T installation for vacuum ionplasma deposition (Fig. 1). It consists of a chamber, a vacuum pumping system, evaporators, a rotary device, a water system and a stand.

\section{Research results}

Fig. 2 shows the nature of damage to parts hardened by ion-plasma chromium plating using advanced technology during the test.

The initial signs of failure of the coating in the form of scoring marks were revealed at the peak in zones " $M$ " and " $F$ " after 300 loading cycles, at the striker in the same areas after 450 cycles. 


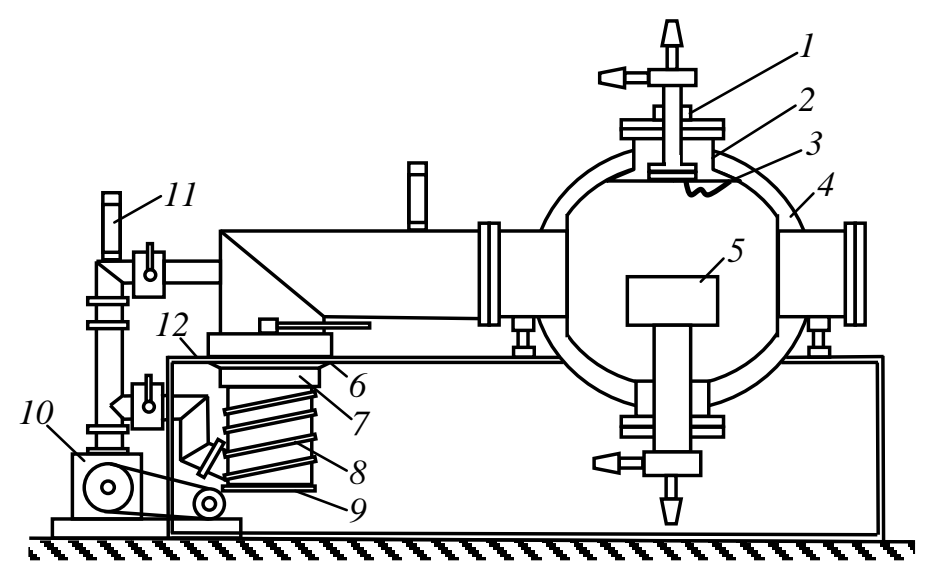

Fig. 1. General scheme of the installation of "Bulat-3T": 1 -focusing coil; 2 - cathode; 3 -ignition electrode; 4 - camera anode; 5 - substrate; 6 - nitrogen trap; 7 -water trap; 8 - high vacuum unit; 9 - heater; 10 - form vacuum pump; 11 - a monometric lamp; 12 - installation water cooling system. The thickness of the applied chrome coating was $50 \ldots 60$ microns

In the cavity of the bushing channel, risks appeared after 600 cycles, in the cavity of the body after 700 loading cycles. In the channels of the housing and the sleeve (zone B) and their slice after 800 cycles cracks formed oriented along the axis of the parts. Due to wear of the coating on the most loaded areas of the device parts, the test was terminated after 1730 loading cycles.

Measurements of worn parts show that the reduced diameter of the channels of the housing and the sleeve in the shear zone increased to $125.5 \mathrm{~mm}$. The firing pin has worn out in zone " $N$ " by 0.2 $\mathrm{mm}$, in zone " $M$ " by $0.5 \mathrm{~mm}$. Peak at $0.3 \mathrm{~mm}$ and $0.85 \mathrm{~mm}$, respectively. The locations of the areas of greatest wear and the nature of the damage to the parts are similar to those observed on the parts investigated above.

In zone "A" of the striker channel (body) and sleeve, wear, hardening and plastic deformation of the metal are observed (Fig. 3). These phenomena are more intense on the sleeve. In zone " $B$ ", wear, plastic deformation of the surface layer and the formation of scoring grooves are visible. On the sleeve, the tops of the furrows are smoothed, worn out (in places to the base); there are rough furrows on the case, with no signs of wear. In zone " $C$ " there is uniform wear, hardening and peeling of the surface layer. Peeling on the body is significant, on the sleeve it is in the initial stage of development. Small areas of the preserved hardened layer are noted on the body. On the housing and the sleeve, the wear of the coating passes without signs of spalling or peeling.

The nature of the damage to the striker and peaks is similar to that observed on previously investigated parts, hardened by ion-plasma chromium plating using the original technology. In the central part of the striker (zone " $N$ "), a smoothed spot with a preserved coating is noted. On the striker, the coating is less worn than on the peak. Zone " $M$ " is characterized by the presence of a relief of scoring grooves, developed to a greater extent at the peak. On the striker as a result of wear, the relief of the furrows is significantly smoothed. It is noted that the degree of development of the furrows of the firing pin and peak differ less than the firing pin and peak of previously studied hardening options. Zone " $F$ " is characterized by wear of the coating, hardening and smoothness of the surface. Damage in this area is uniform along the circumference of the parts and is almost the same at the striker and peak. Traces of running-in and hardening of the coating are observed in zone " $E$ ". Along the contour of the parts, a coating of metal on the edge of the cylindrical surface is noted. 


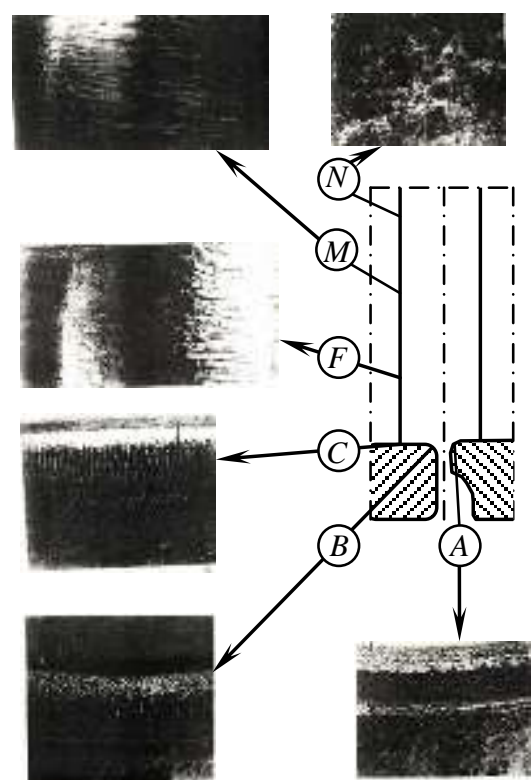

$\times 100$

Fig. 2. Wear peaks and bushings, hardened by ionplasma chromium plating (by advanced technology)

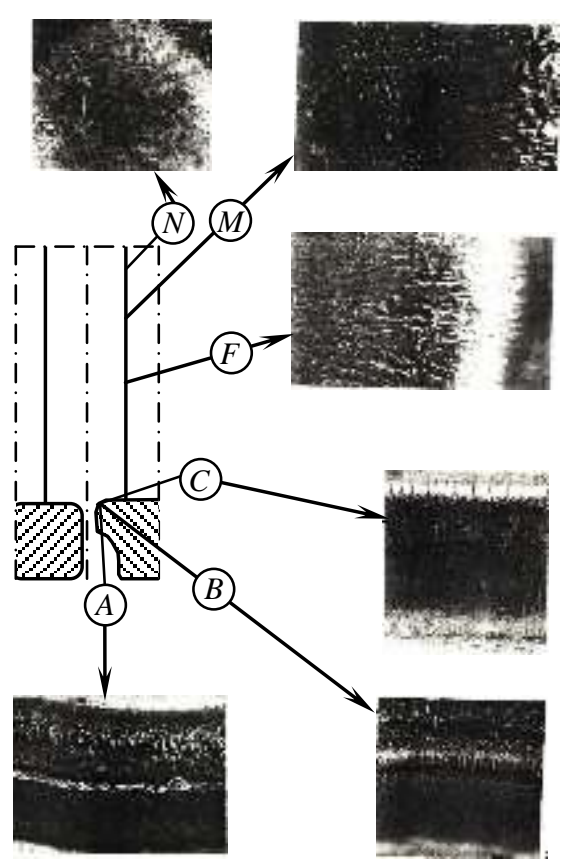

$\times 100$

Fig. 3. Deterioration of the hull and die, hardened by ion-plasma chrome plating (advanced technology)

Cracks are observed on the tested parts of the investigated variant (Fig. 4, 5).

Cracks on the body and sleeve are observed in zones " $A$ " and " $B$ ". Their depth on the case reaches $0.55 \mathrm{~mm}$, on the sleeve $-0.4 \mathrm{~mm}$. There are no cracks in zone " $C$ ". On the striker, cracks are fixed in zone " $N$ " up to $0.3 \mathrm{~mm}$ deep and in zone " $M$ " up to $0.6 \mathrm{~mm}$. At the peak, cracks are observed only in the " $M$ " zone up to $0.6 \mathrm{~mm}$ deep.

The type of fractures in kinks is similar to that previously observed on other hardening options (contoured contour, oxidation and smoothness of the surface).

On the housing and the sleeve, coating residues are observed in zones " $A$ " and " $C$ ".

The thickness of the preserved coating on the sleeve in zones " $A$ " and " $C$ " is $10 \mu \mathrm{m}$, on the body (channel) in zone " $C$ " up to $10 \mu \mathrm{m}$. At the striker and peak, coverage was preserved only in zones " $N$ " and " $E$ ". The layer thickness at the striker is $10 \mu \mathrm{m}$, at the peak up to $5 \mu \mathrm{m}$.

Structural changes are observed in the metal of the investigated parts in the damage zones. On the sleeve, structural transformations to a depth of $0.25 \ldots 0.30 \mathrm{~mm}$ are noted in zones " $A$ " and " $B$ ", on the top - to a depth of $0.15 \ldots 0.20 \mathrm{~mm}$ in zones " $A$ ", " $B$ " and " $C$ ". The hardness of the material in the zones of structural transformations is HV $510 \ldots 645$.

In the material, peaks of structural changes to a depth of $0.25 \ldots 0.30 \mathrm{~mm}$ are observed in zones " $N$ " and " $M$ ". At a striker in the same zones, the depth of structural changes is $0.15 \ldots 0.20 \mathrm{~mm}$. The hardness of the material in the zones of structural changes is HV $510 \ldots 585$.

The hardness of the material of the investigated parts is:

sleeve - HRC 40...42; peak - HRC 40...42;

case - HR C40...42; striker - HRC 40...42.

Microstructure of the material of sorbitol-type parts, finely dispersed structure. The test results of the mechanical properties of the material of the parts in tension are presented in Table. 


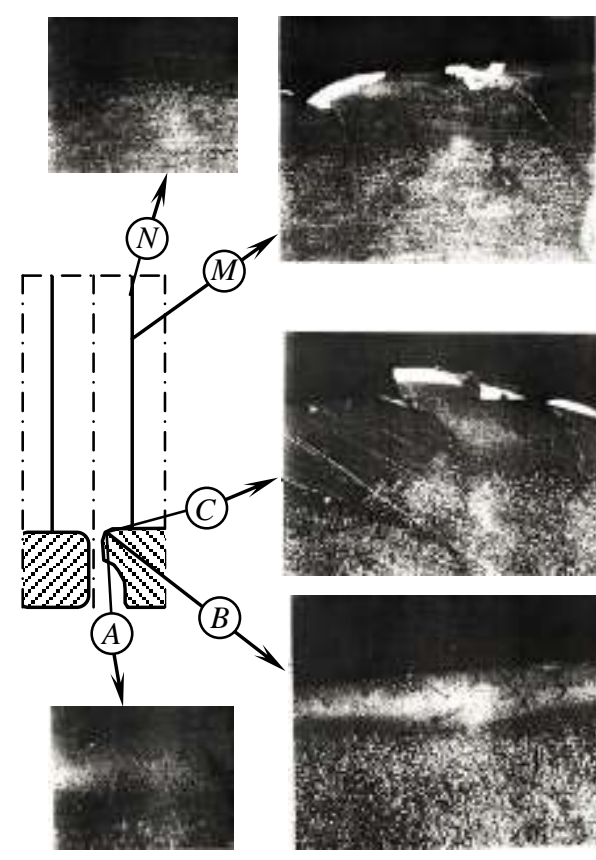

$\times 100$

Fig. 4. Structural changes in the material of the body and hammer, hardened by ion-plasma chromium plating (by advanced technology)

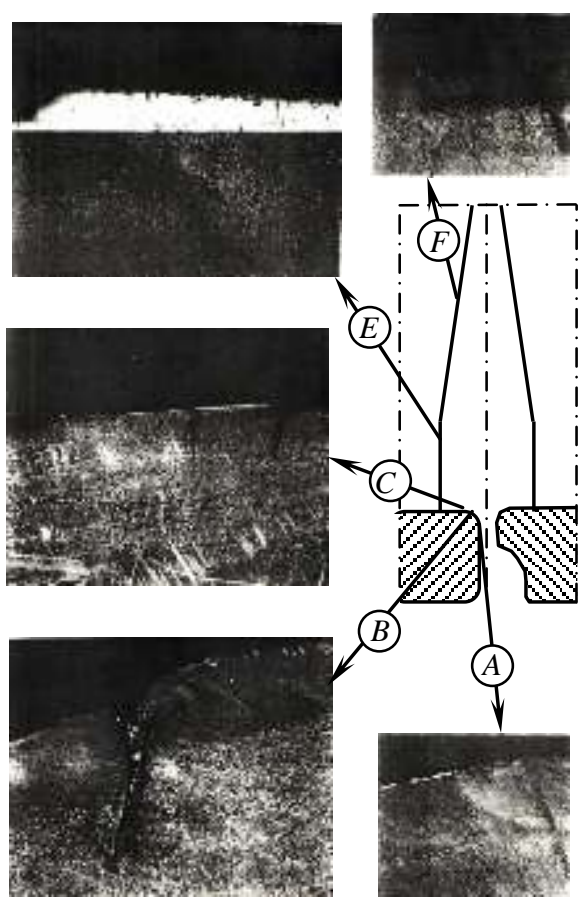

$\times 100$

Fig. 5. Structural changes in the material of the peaks and bushings hardened by ion-plasma chromium plating (using advanced technology)

Mechanical properties of the material of parts hardened by ion-plasma chromium plating (using advanced technology)

\begin{tabular}{c|c|c|c|c|c}
\hline \multirow{2}{*}{$\begin{array}{c}\text { The name of } \\
\text { detail }\end{array}$} & $\begin{array}{c}\text { Sample cutting } \\
\text { direction }\end{array}$ & $\sigma_{\mathrm{B}}, \mathrm{MPa}$ & $\sigma_{0.2}, \mathrm{MPa}$ & $\delta, \%$ & $\psi, \%$ \\
\cline { 3 - 6 } & axial & $1390.0 \ldots 1430.0$ & $1310.0 \ldots 1360.0$ & 8.0 & 23.0 \\
\hline \multirow{2}{*}{ Striker } & tangential & 1490.0 & $1400.0 \ldots 1430.0$ & 15.0 & 56.0 \\
\cline { 2 - 6 } & axial & 1460.0 & 1380.0 & $6.4 \ldots 8.0$ & $3.0 \ldots 15.0$ \\
\cline { 2 - 6 } Peak & tangential & $1450.0 \ldots 1510.0$ & $1360.0 \ldots 1375.0$ & 13.0 & $51.0 \ldots 54.0$ \\
\hline
\end{tabular}

\section{Conclusions} creased.

The wear resistance of critical parts of the hydraulic hammer by ion-plasma treatment is in-

Based on experimental studies, the following tasks were solved:

1. The analysis of the damaged working surfaces of the tested parts of the hydraulic hammer by the nature and location of the zones.

2. The technological process of hardening is developed. Improved wear resistance of parts hardened by ion-plasma chromium plating using advanced technology. The test results of parts hardened by ion-plasma chromium plating using advanced technology indicate that their wear resistance is increased by $\sim 1.75$ times compared to the original (not subjected to special hardening).

3. The effect of ion-plasma treatment on the nature of damage to the hydraulic hammer coatings and on the wear of the lower parts (sleeve, peak) is investigated. Damage to the working surfaces of the tested parts by the nature and location of the zones is similar to the previously investigated parts. 
Damage to parts is characterized by wear of the coating, metal hardening, the formation of scoring grooves and cracks. In the most loaded parts of the parts (in zones " $\mathrm{B}$ " and " $\mathrm{C}$ " on the striker body and sleeve and "M" and " $\mathrm{F}$ " on the striker and peak), the hardening coating is almost completely worn out. The advanced technology of ion-plasma chromium plating ensures the work of hardened parts without chips and chipping of the coating. A feature of the test results of this variant of hardening is less wear of the lower parts (sleeve, peak) compared to the upper ones.

4. The change in the structure and properties of hardened surface areas of the investigated parts in the process of operation was investigated. In the areas of damage to parts, zones of structural transformations of the material to a depth of $0.3 \mathrm{~mm}$, characteristic of secondary hardening phenomena, are noted. There are cracks on all the parts: on the body and sleeve in zones "A" and " $B$ " up to $0.55 \mathrm{~mm}$, on the striker and peak in the zone up to $0.6 \mathrm{~mm}$. In the remaining areas, damage to the details of the cracks was not detected.

\section{Література}

1. Виноградов М.И., Маншев Ю.П. Вакуумные процессы и оборудование ионно- и электроннолучевой технологии. Москва : Машиностроение, 2009. 56 c.

2. Гришин С.Д., Лесков Л.В., Козлов Н.П. Плазменные ускорители. Москва : Машиностроение, 2003. $174 \mathrm{c}$.

3. Пархоменко В.Д., Цыбулев П.Н., Краснокутский Ю.И. Технология плазмохимических производст. Киев : Вища школа, 2001. 255 с.

4. Большаков В.І., Глушкова Д.Б., Воронова Є.М. Дослідження особливостей лазерного борування поршневих кілець. Вісник Придніпровської державної академії будівництва та архітектури. 2015. No 11 (212). C. 27-31.

5. Спосіб хіміко-термічної обробки деталей із металів і сплавів: пат. 45841 Україна. В 22 F 3/24; заявл. 19.07.2001; опубл. 15.04.2002, Бюл. № 4.

6. Способ комплексной химико-термической обработки изделий из углеродистых сталей и спечённых материалов на основе железа: пат. 1157127 СССР, С 23 С 8/78; подано 26.04.83; опубл. 23.05.85, Бюл. № 19.

7. Кэмбл Дж. Артур. Современная общая химия: пер. с англ. : в 3-х т. Пер. с англ. Москва : Мир, 1974. Т. 1.545 c.

8. Глушкова Д.Б., Костина Л.Л. Повышение долговечности ответственных деталей гидромолота : монография. Харьков : LAP LAMBERT Academic Publishing, 2018. 265 c. ISBN: 978-613-9-82877-7.

9. Овчаров В.П. Повышение износостойкости деталей цилиндропоршневой группы компрессоров КТ обработкой в атмосфере пара. Вестник машиностроения. 1980. №4. С. 31-32.

10. Гладкова Е.Н., Советова Л.В. К вопросу о составе газовой смеси при паротермическом оксидировании. Тр. НИТИ. 1967. Вып. 2. С. 60-62.

11. Тихомиров В.И., Гофман И.А., Ипатьев В.В. Скорость окисления железа в водяном паре и углекислом газе при высоких температурах. Уч. записки ЛГУ. Серия Химия. 1964. Вып. 14, ч. 1. № 175. C. 14-17.

12. Калинина Н.Е., Юхименко А.Е., Калинин В.Т. Особенности строения и свойств модифицированных жаропрочных сплавов. Строительство, материаловедение, машиностроение: сб. н. тр. ПГАСА. 2015. Вып. 80. С. 158-162.

13. Вплив фазового складу наплавлених шарів штоків ідроиліндрів на їх локальну корозію / А.А. Голякевич та ін. Фізико-хімічна механіка матеріалів. 2014. Том 50, № 5. С.104-110.

\section{References}

1. Vinogradov, M.I., \& Manshev, Yu.P. (2009). Vacuum processes and equipment for ion and electron beam technology. Moscow: Engineering.

2. Grishin, S.D., Leskov, L.V., \& Kozlov, N.P. (2003). Plasma Accelerators. Moscow: Mechanical Engineering.

3. Parkhomenko, V.D., Tsybulev, P.N., \& Krasnokutsky, Yu.I. (2001). Technology of plasma chemical production. Kiev: Vishka school. 
4. Bolshakov, V., Hlushkova, D., \& Voronova, Ye. (2015). Investigation of peculiarities of piston rings laser berating. Bulletin of PGASA, 11, 27-31.

5. Timofeeva, L.A., Proskurina, L.V., Fedchenko, I.I., \& Timofeev S.S. (2002). Patent 45841. Method of chemical-thermal processing of parts made of metals and alloys. Ukraine.

6. Borisenko, G.V., Galinskaya, N.A., \& Kulikovsky, E.A. (1985). Patent 1157127. Method of complex chemical-thermal treatment of products from carbon steels and sintered materials based on iron. USSR.

7. Kemble J. Arthur. (1974). Modern General Chemistry: Tr. from English : in 3 v. Tr. from English, Moscow: World, V. 1.

8. Hlushkova, D.B., \& Kostina, L.L. (2018). Increasing the durability of the responsible parts of the hydraulic hammer. Kharkov: LAP LAMBERT Academic Publishing. ISBN: 978-613-9-82877-7.

9. Ovcharov, V.P. (1980). Improving the wear resistance of parts of a cylinder-piston group of CT compressors by treatment in a steam atmosphere. Bulletin of mechanical engineering, 4, 31-32.

10. Gladkova, E.N., \& Sovetova, L.V. (1967). On the question of the composition of the gas mixture during steam-thermal oxidation. Tr. THREADS, 2, 60-62.

11. Tikhomirov, V.I., Hoffman, I.A., \& Ipatiev, V.V. (1964). The oxidation rate of iron in water vapor and carbon dioxide at high temperatures. Uch. LSU notes. Series Chemistry, 14, 1, 175, 14-17.

12. Kalinina, N.E., Yukhimenko, A.E., \& Kalinin, V.T. (2015). Features of the structure and properties of modified heat-resistant alloys. Construction, materials science, mechanical engineering, 80, 158-162.

13. Golyakevich, A.A. et al. (2014). Injection into the phase deposition of the deposition of the spheres of the stocks and the joints on the local corrosion. Physics and Mechanics of Materials, 50, 5, 104-110.

Глушкова Діана Борисівна; Hlushkova Diana, ORCID: https://orcid.org/0000-0001-8612-6584

Воронков Олександр Іванович; Voronkov Oleksandr, ORCID: https://orcid.org/0000-0002-8389-2459

Кириченко Ігор Георгиевич; Kirichenko Igor, ORCID: http://orcid.org/0000-0002-2128-3500

Ніконов Олег Якович; Nikonov Oleg, ORCID: http://orcid.org/0000-0002-8878-4318

Received May 12, 2020

Accepted June 10, 2020 